\title{
COMPARISON OF PLANT GROWTH-PROMOTION WITH PSEUDOMONAS AERUGINOSA AND BACILLUS SUBTILIS IN THREE VEGETABLES
}

\author{
A.O. Adesemoye ${ }^{1,3}$; M. Obini²; E.O. Ugoji ${ }^{2}$ \\ ${ }^{1}$ Department of Microbiology, Adekunle Ajasin University, P. M. B. 001, Akungba-Akoko, Ondo State, Nigeria; ${ }^{2}$ Department of \\ Botany and Microbiology, University of Lagos, Lagos, Nigeria; ${ }^{3}$ Current Address: Department of Entomology \& Plant \\ Pathology, 209 Life Sciences Building, Auburn University, Auburn, Alabama, USA.
}

Submitted: June 19, 2007; Returned to authors for corrections: December 13, 2007; Approved: July 05, 2008.

\section{SHORT COMMUNICATION}

\begin{abstract}
Our objective was to compare some plant growth promoting rhizobacteria (PGPR) properties of Bacillus subtilis and Pseudomonas aeruginosa as representatives of their two genera. Solanum lycopersicum L. (tomato), Abelmoschus esculentus (okra), and Amaranthus sp. (African spinach) were inoculated with the bacterial cultures. At 60 days after planting, dry biomass for plants treated with B. subtilis and $P$. aeruginosa increased $31 \%$ for tomato, $36 \%$ and $29 \%$ for okra, and $83 \%$ and $40 \%$ for African spinach respectively over the non-bacterized control. Considering all the parameters tested, there were similarities but no significant difference at $\mathrm{P}<0.05$ between the overall performances of the two organisms.
\end{abstract}

Key-words: PGPR, Pseudomonas aeruginosa, Bacillus subtilis, growth promotion

Many species and specific strains of bacteria have been investigated as plant growth-promoting rhizobacteria (PGPR) in different parts of the world on different plants. The impact of rhizobacteria generally on plant growth and health may be classified as neutral, deleterious or beneficial (12). However, PGPR specifically are beneficial and the beneficial effects have been utilized in many areas including biofertilizer, disease control, microbe-rhizoremediation, biopesticide, in forestry $(11,13,14)$ as well as probiotics (15).

Different bacteria that have been reported as PGPR belong to the following genera: Pseudomonas, Bacillus, Azospirillum, Agrobacterium, Azotobacter, Arthrobacter, Alcaligenes, Serratia, Rhizobium, Enterobacter, Burkholderia, Beijerinckia, Klebsiella, Clostridium, Vario-vovax, Xanthomonas, and Phyllobacterium (4-6,10,13,14,16,18). Among these, Pseudomonas and Bacillus are the most widely reported PGPR.

Growth promotion and disease control by Pseudomonas and Bacillus are complex interrelated processes involving direct and indirect mechanisms that include synthesis of some metabolites (auxin, cytokinin and gibberellins), induction of 1aminocyclopropane-1-carbocylate (ACC) deaminase, production of siderophore, antibiotics, hydrogen cyanide $(\mathrm{HCN})$, and volatile compounds. Others include mineral solubilization (e.g., phosphorus), competition, and induced systemic resistance $(8,9,11,16,17,20)$. In these processes there are some similarities and differences between Pseudomonas and Bacillus based on the reports of different authors cited above.

However, the relative competence of these two important genera is not clear. To our knowledge, no reports are available presenting a comparison between them under the same study conditions. We agree with a previous assertion that comparative studies between crop types and different species and strains of rhizobacteria are currently missing in PGPR research (13). The objective of this work was therefore to do a comparative study of the PGPR (or plant probiotic) properties between the genera of Pseudomonas and Bacillus. In order to make this generalization, strains of Pseudomonas aeruginosa and

*Corresponding Author. Mailing address: Department of Microbiology, Adekunle Ajasin University, P.M.B. 001, Akungba-Akoko, Ondo State, Nigeria. Tel.: 1-334-844-1982. E-mail: semoyet@yahoo.co.uk/ adeseao@auburn.edu 
Bacillus subtilis were used as representatives since they are important species of each of the genera.

In the preliminary trials with P. aeruginosa and P. putida, only this chosen strain of $P$. aeruginosa showed consistency in growth promotion and this explains its choice and similarly, that of the B. subtilis.

Soil used in this study was collected from the Botanical Garden of the University of Lagos, Lagos, Nigeria. Soil was analyzed as reported previously (1). Bacillus subtilis was isolated from the soil and to do that, $9 \mathrm{ml}$ of distilled water was added to $1 \mathrm{~g}$ of soil sample in a macrophage tube. This was agitated for $2 \mathrm{~min}$ to ensure thorough mixing. The tube was placed in a hot water bath at $80^{\circ} \mathrm{C}$ for $10 \mathrm{~min}$ to kill non-sporeforming mesophiles. The heat-treated soil sample was serially diluted and inoculation onto nutrient agar plates was done using $10^{-4}$ dilution by spread plate technique. Sterile glass spreader (hockey stick) was used for inoculum spread. The plates were incubated aerobically at $37^{\circ} \mathrm{C}$ for $48 \mathrm{~h}(3,7)$. Identification of $B$. subtilis was done by physiological and standard biochemical tests $(2,4)$ but the previously identified $P$. aeruginosa $(1)$ was used in this study.

Test plants included three vegetables - Abelmoschus esculentus (okra), Solanum lycopersicum L. (formerly Lycopersicon esculentum L.) (tomato) and Amaranthus sp. (African spinach), which were selected to ensure that at least one of them was available in any part of the world. Seeds of these test plants were obtained from the Ondo State Agricultural Development Program (ADP), Akure, Ondo State, Nigeria. Seeds were surface disinfected by modifying the method used by Ryu et al. (17) and then inoculated with bacterial cultures containing $10^{6} \mathrm{cfu} / \mathrm{ml}$ by seed soaking using the same method by Adesemoye and Ugoji (1). Three seed treatments for each of the test plants include seeds inoculated with the strain of $P$. aeruginosa, seeds inoculated with the strain of $B$. subtilis, and seeds soaked in distilled water (control). Treated seeds were sown in planting pots $(20 \mathrm{~cm}$ in diameter) containing $2 \mathrm{~kg}$ of field soil. Each treatment consisted of five replicates per plant. Plants were watered with tap water once in two days using a watering can. Experiments were conducted in the glasshouse at the Botanical Garden, University of Lagos, Nigeria but seed germination was monitored in the laboratory. In the laboratory, the numbers of seedlings that emerged at 3 days after planting (DAP) were manually counted. In the glasshouse, shoot height of plants was measured at 10-day intervals over 60 DAP. The numbers of days for tomato and okra to produce their first fruits were recorded. All plants were harvested at 65 DAP and rhizosphere soil was washed in slow running water. Excess water was allowed to drain, fresh weights were taken, drying was done at $70^{\circ} \mathrm{C}$ for $48 \mathrm{~h}$ and dry weights were recorded $(1,3)$. Data were analyzed using SAS 9.1 software (SAS Institute, Cary, NC). Treatment means were separated by least significant differences at $\mathrm{P}<0.05$ and box plot was done.
Both strains of P. aeruginosa and B. subtilis enhanced the emergence of seedlings at 3 DAP. The performances of the two inoculants were not significantly different for tomato and African spinach. In tomato, both inoculants recorded 50\% improvement in germination rate over the control. In African spinach, both inoculants recorded $40 \%$ increase over the control. However, for okra, $80 \%$ improvement in emergence was recorded for those treated with B. subtilis while $60 \%$ improvement was recorded for okra treated with P. aeruginosa over the control (Table 1). The remaining seedlings that emerged after 3 days of planting were not considered for this analysis because at 3 DAP about $90 \%$ of all treated seeds had emerged.

In all the test plant species, both inoculants enhanced growth that was significantly greater than the control. The improvement of plant growth over the control ranged between $30 \%$ and $80 \%$ depending on the plant species. Among the inoculants, differences were not statistically significant at $P<0.05$. Although mean shoot heights for tomato and African spinach plants treated with $P$. aeruginosa were slightly greater than B. subtilis, an opposite trend was observed for okra plants; however, the differences were not significant. For instance, in tomato mean shoot height of B. subtilis was $58.9 \mathrm{~cm}$ compared to $62.0 \mathrm{~cm}$ in $P$. aeruginosa but both were significantly different from $46.0 \mathrm{~cm}$ of the control (Fig. 1).

The impacts of the inoculants showed a similar trend for dry biomass. Differences between treatments in terms of dry biomass were not significant among the inoculants, but both were statistically greater than the control. At 65 DAP, mean dry biomass of tomato plants treated with $B$. subtilis or P. aeruginosa increased $31 \%$ compared to the non-bacterized control, while with okra, the biomass increase with $B$. subtilis was $36 \%$ and $29 \%$ with P. aeruginosa. Only in African spinach was the difference between the inoculants significant; improvement over the control was $83 \%$ and $40 \%$ for B. subtilis and P. aeruginosa respectively (Fig. 2).

Table 1. Seedling emergence at 3 days after planting and number of days for first fruit.

\begin{tabular}{lccccc}
\hline \multirow{2}{*}{ Organism } & \multicolumn{2}{c}{$\begin{array}{c}\text { Seedling emergence } \\
\text { at 3 DAP* }\end{array}$} & \multicolumn{2}{c}{$\begin{array}{c}\text { Days for } \\
\text { first fruit }^{\Delta}\end{array}$} \\
\cline { 2 - 6 } & Tomato & Okra & $\begin{array}{c}\text { A. } \\
\text { spinach }\end{array}$ & Tomato & Okra \\
\hline B. subtilis & $90 \%(50)$ & $90 \%(80)$ & $70 \%(40)$ & $56 \mathrm{~b}$ & $47 \mathrm{~b}$ \\
P. aeruginosa & $90 \%(50)$ & $80 \%(60)$ & $70 \%(40)$ & $56 \mathrm{~b}$ & $45 \mathrm{~b}$ \\
Control & $60 \%$ & $50 \%$ & $50 \%$ & $65 \mathrm{a}$ & $59 \mathrm{a}$ \\
\hline
\end{tabular}

* Numbers in parentheses in the table represent percentage increases of germination rate relative to the control. ${ }^{\Delta}$ Numbers with different letters are significantly different at $\mathrm{P}<0.05$, Least significant Difference test. 




Figure 1. Comparison of plant shoot heights of three vegetable species inoculated with two PGPR. Bars with different letters are significantly different at $\mathrm{P}<0.05$, Least Significant Difference test.

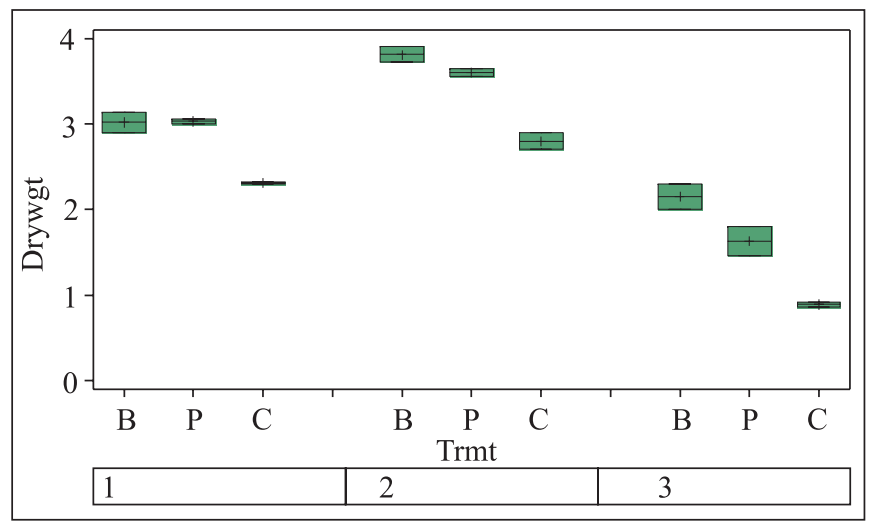

Figure 2. In the treatments above $\mathrm{B}$ is $B$. subtilis, $\mathrm{P}$ is $P$. aeruginos $a$, and $\mathrm{C}$ is Control (without inoculant). The numbers in the box represent test plants - 1, 2, 3 are tomato, okra and African spinach respectively. Dry weight (Drywgt) on the vertical axis is in gram. DAP means days after planting.

The mean day for first fruit in tomato plants was the same 56 DAP for the two inoculants (P. aeruginosa and B. subtilis) compared to 65 days of the control. In okra, test plants from seeds treated with $P$. aeruginosa started fruit production two days earlier (45th DAP) than those of B. subtilis (47th DAP), and plants from seeds soaked in sterile distilled water commenced fruiting on 59th DAP (Table 1).
Our results confirm growth promotion by one representative each of both species of bacteria (Pseudomonas and Bacillus), but little variations were observed in bacterial effectiveness among parameters and vegetable types. Considering all parameters tested in this study (seedling emergence, shoot height, days of production of first fruit and dry biomass), there were similarities but no significant difference between the overall performance of Pseudomonas and Bacillus. Based on the results, none of the representative organisms (of the two genera) in this study is a better PGPR than the other. However, with the ability of Bacillus to form heat and desiccation resistant endospores, they may be relatively more versatile than Pseudomonas since such spores can retain viability for long periods either in storage or in the soil $(10,20)$. Although the $P$. aeruginosa isolate used in this study was not pathogenic, it was handled with great care. As more information became available on the opportunistic human pathogenic properties of $P$. aeruginosa (19), we highly discourage its use in related future studies; rather other species of Pseudomonas could be used. We recommend further comparative studies of the PGPR properties between many representatives of the two genera.

\section{RESUMO}

\section{Comparação da promoção de crescimento de plantas por Pseudomonas aeruginosa e Bacillus subtilis em três vegetais}

Nosso objetivo foi comparar as propriedades PGPR (rizobactérias promotoras de crescimento de plantas) de Bacillus subtilis e Pseudomonas aeruginosa. Solanum licopersicum (tomate), Asbelmoschus esculentus (ocra) e Amaranthus sp (espinafre africano) foram inoculados com as culturas bacterianas. Após 60 dias de plantio, a biomassa seca das plantas tratadas com B.subtilis e P. aeruginosa aumentou $31 \%$ para o tomate, $36 \%$ e $29 \%$ para ocra, e $83 \%$ e $40 \%$ para espinafre africano, respectivamente, em comparação com o controle não inoculado. Considerando os parâmetros testados, o desempenho dos dois microrganismos foi similar, sem diferença estatisticamente significativa $(p<0,05)$.

Palavras-chave: PGPR, Pseudomonas aeruginosa, Bacillus subtilis, promoção de crescimento

\section{REFERENCE}

1. Adesemoye, A.O.; Ugoji, E.O. (2006). Evaluating Pseudomonas aeruginosa as plant growth-promoting rhizobacteria (PGPR) in West Africa. Arch. Phytopathol. Plant Protect. Online PrEview, 1-13 (DOI: 10.1080/03235400601014791).

2. Anon (1994). Bergey's manual of determinative bacteriology. Holt, J.G.; Krieg, N.R.; Sneath, P.H.A.; Staley, J.T.; Williams, S.T. (ed). Williams and Wilkins, Baltimore, USA. 
3. Bai, Y.; D'Aoust, F.; Smith, D.L.; Driscoll, B.T. (2002). Isolation of plant-growth-promoting Bacillus strains from soybean root nodules. Can. J. Microbiol., 48, 230-238.

4. Bullied, W.J.; Buss, T.J.; Vessey, J.K. (2002). Bacillus cereus UW85 inoculation effects on growth, nodulation and $\mathrm{N}$ accumulation in grain legumes: Field studies. Can. J. Plant Sci., 82, 291-298.

5. De Freitas, J.R.; Germida, J.J. (1990). Plant growth promoting rhizobacteria for winter wheat. Can. J. Microbiol., 36, 265-272.

6. De Silva, A.; Patterson, K.; Rothrock, C.; Moore, J. (2000). Growth promotion of highbush blueberry by fungal and bacterial inoculants. Hort. Sci., 35, 1228-1230.

7. De Souza, A.N.; Martins, M.L. (2001). Isolation, properties, and kinetics of growth of a thermophilic Bacillus. Braz. J. Microbol., $32,271-275$.

8. Glick, B.R.; Jacobson, C.B.; Schwarze, M.M.; Pasternak, J.J. (1994). 1-Aminocyclopropane-1-carboxylic acid deaminase mutants of the plant growth-promoting rhizobacterium Pseudomonas putida GR122 do not stimulate canola root elongation. Can. J. Microbiol., 40, 911-915.

9. Joo, G.-J.; Kim, Y.-M.; Lee, I.-J.; Song, K.-S.; Rhee, I.-K. (2004). Growth promotion of red pepper plug seedlings and the production of gibberellins by Bacillus cereus, Bacillus macroides, and Bacillus pumilus. Biotechnol. Lett., 26, 487-491.

10. Kim, D-S.; Cook, R.J.; Weller, D.M. (1997). Bacillus sp. L324-92 for biological control of three root diseases of wheat grown with reduced tillage. Phytopathol., 87, 551-558.

11. Kloepper, J.W. (2003). A review of mechanisms for plant growth promotion by PGPR. Presented at the 6th International PGPR Workshop, 5-10 October 2003, Calicut, India.
12. Kloepper, J.W.; Lifshitz, R.; Zablotowicz, R.M. (1989). Free-living bacterial inocula for enhancing crop productivity. Trends Biotechnol., 7, 39-44.

13. Lucy, M.; Reed, E.; Glick, B.R. (2004). Application of free living plant growth-promoting rhizobacteria. Antonie van Leeuwenhoek $86,1-25$.

14. Lugtenberg, B.J.; Chin-A-Woeng, T.F.; Bloemberg, G.V. (2002). Microbe-plant interactions: principles and mechanisms. Antonie van Leeuwenhoek, 81, 373-383.

15. Nicholson, W.L. (2002). Roles of Bacillus endospores in the environment. CMLS, Cell. Mol. Life Sci., 59, 410-416.

16. Quadt-Hallmann, A.; Hallmann, J.; Kloepper, J.W. (1997). Bacterial endophytes in cotton: location and interaction with other plantassociated bacteria. Can. J. Microbiol., 43, 254-259.

17. Ryu, C.; Farag, M.A.; Hu, C.-H.; Reddy, M.S.; Wei, H.-X.; Pare, P.W.; Kloepper, J.W. (2003). Bacteria volatiles promote growth in Arabidopsis. Proc. Nat. Acad. Sci., (USA) 100, 4927-4932.

18. Saubidet, M.I.; Fatta, N.; Barneix, A.J. (2002). The effect of inoculation with Azospirillum brasilense on growth and nitrogen utilization by wheat plants. Plant. Soil., 245, 215-222.

19. Wu, L.; Estrada, O.; Zaborina, O.; Bains, M.; Shen, L.; Kohler, J.E.; Patel, N.; Musch, M.W.; Chang, E.B.; Fu, Y.-X.; Jacobs, M.A.; Nishimura, M.I.; Hancock, R.E.W.; Turner, J.R.; Alverdy, J.C. (2005). Recognition of Host Immune Activation by Pseudomonas aeruginosa. Science, 309 (5735), 774-777. [DOI: 10.1126/science. 1112422].

20. Young, C.S.; Lethbridge, G.; Shaw, L.J.; Burns, R.G. (1995). Survival of inoculated Bacillus cereus spores and vegetative cells in nonplanted and rhizosphere soil. Soil Biol. Biochem., 27, 1017-1026. 